\title{
Exploration and Practice of Student-Centered "Ternary" Talent Cultivation Mode
}

\author{
Xitai Na, Zhi Weng*, Zhiqiang Zheng, Junlin Wang, Ding Han, Yongfeng Wei, Caili Gong \\ College of Electronic Information Engineering, Inner Mongolia University, Huhhot, China \\ Email: *wzhi@imu.edu.cn
}

How to cite this paper: $\mathrm{Na}, \mathrm{X}$. T., Weng, Z., Zheng, Z. Q., Wang, J. L., Han, D., Wei, Y. F., \& Gong, C. L. (2021). Exploration and Practice of Student-Centered "Ternary" Talent Cultivation Mode. Creative Education, 12, 2116-2123.

https://doi.org/10.4236/ce.2021.129162

Received: August 1, 2021

Accepted: September 21, 2021

Published: September 24, 2021

Copyright $\odot 2021$ by author(s) and Scientific Research Publishing Inc. This work is licensed under the Creative Commons Attribution International License (CC BY 4.0).

http://creativecommons.org/licenses/by/4.0/

\begin{abstract}
"Student-centered" is the essential requirement of higher education in the new era, and the inevitable requirement of the reform of higher education talent cultivation mode, as well as the starting point and end-result of the innovation of teaching mode. College of Electronic Information Engineering of Inner Mongolia University takes the opportunity of Undergraduate Engineering Education Accreditation and Undergraduate Professional Certification to explore the "student-centered" talent cultivation mode, building "students as the center, learning + teaching + innovative practice experience" ternary supporting talent cultivation mode. To be specific, "student-centered" innovation talent cultivation as the main line, "virtue and goodness" and "dedication to learning and innovation" as the cultivation objective, cultivating students' knowledge, ability and quality as the fundamental, three measures are adopted to cultivate high-quality specialized technical talents. The measures mainly include building a diversified cultivation system to promote the transformation of students' learning mode, deepening the reform of curriculum structure to promote the transformation of teachers' teaching mode, building a platform for entrepreneurship and innovation education to enhance students' practical experience. Practice shows that the mode can help students form comprehensive literacy to solve practical problems, forward-looking professional vision and autonomous lifelong learning ability.
\end{abstract}

\section{Keywords}

Higher Education of New Era, Student-Centered, Talent Cultivation Mode

\section{Introduction}

In 1952, Carl R. Rogers, an American psychologist, first proposed the concept of "student-centered" and applied it to undergraduate education. In 1998, the Declaration of the World Conference on Higher Education "Higher Education in the 
Twenty-first Century: Vision and Action" pointed out that "higher education clearly needs new perspective and new mode centered on students in today's rapidly changing world" (Li, 2008). "Student-centered" has been widely accepted and recognized by educators as an educational concept of school administration (Xu et al., 2018). "Student-centered" takes quality improvement of talent cultivation as the center, as well as the life-long development, learning initiative, and the learning efficiency of students as the center (Yu, 2018).

The reform of talent training mode in universities must take "student-centered" as the starting point, pay attention to stimulating students' learning interest and potential in many aspects, levels and angles, innovate classroom teaching forms, reform teaching methods, strengthen practical teaching, promote the transformation of undergraduate teaching from "teaching well" to "learning well", and make teaching truly return to the essence of "learning".

Deepening the reform of "student-centered" talent cultivation mode is an important way for colleges and universities to improve the quality of talent cultivation. On the basis of a deep understanding of the connotation of "studentcentered" training mode, College of Electronic Information Engineering of Inner Mongolia University combing the actual situation, actively explores the "studentcentered" talent cultivation mode.

Since the new era, under the background of the transformation from "teacher-centered" to "student-centered" talent cultivation in China's higher education, College of Electronic Information Engineering has been supported by the National "Project 211", "The State Program for Building One High-level University in Each of The Provinces in the Mid-western Region, "Project of One Province, One University" and "A University of Co-sponsorship by The Ministry of Education". College of Electronic Information Engineering centered on the fundamental problem that "for whom to cultivate talent, cultivating what kind of talent, and how to cultivate talent", establishing moral integrity as the fundamental, taking the student as the center, and considering student's all-round development as the starting point and the foothold, insistently innovates talent cultivation system, optimizes the structure of curriculum system, strengthens the quality of undergraduate teaching resource construction, deepens the reform of personnel training mode, so as to consistent the undergraduate talent training mode with the requirements of innovative talent cultivation and student growth.

Since 1999, Inner Mongolia University has adjusted and optimized the professional curriculum system structure for four times successively, continuously increased the proportion of professional elective courses, continuously strengthened the construction of professional courses, and improved the level of course construction. It has a number of first-class courses at the Inner Mongolia autonomous region level, first-class courses at university level, and a batch of curriculum ideological and political demonstration courses. Since 1999, on the basis of strengthening general education, after two times of adjustment and optimization, five categories of general education curriculum systems have been reconstructed. Since 2003, the college has increased the strength of experimental practice and train- 
ing, in the meanwhile, it has continuously increased the education of innovation and entrepreneurship for students, and built the innovation and entrepreneurship practice base, namely "Innovation Laboratory" of Inner Mongolia University. More than ten years of undergraduate teaching reform and construction have laid a solid foundation for further innovation of talent cultivation system and reform of talent cultivation mode.

\section{Ideas on the Reform of Talent Cultivation Mode}

On the basis of summarizing and reflecting the teaching reform and construction experience of the previous period, Inner Mongolia University conscientiously implement the spirit in "Several Opinions of Ministry of Education on Comprehensively Improving the Quality of Higher Education" (Ministry of Education, 2012). In view of the problems existing in traditional talent cultivation mode, such as in students' learning pattern, in teacher's teaching pattern, in innovative practice experiencing pattern and in teaching management system, Inner Mongolia University has put forward a series of idea combining "professional education, general education, innovative entrepreneurship education, and growth education", and has also promoted the organic combination of "learning", "teaching" and "innovative practice experience", building the "students as the center, learning + teaching + innovative practice experience" ternary supporting talent cultivation mode, which aims at innovating talent cultivation system, improving the quality of teaching and talent cultivation.

Compared with the traditional talent cultivation mode, the new talent cultivation mode has the basic characteristics of improving students' learning subjectivity, intensifying teachers' teaching dominance and strengthening students' innovative practice experience, aiming at promoting students' all-rounded and personalized development.

"Learning" refers to students' ability to stimulate their own endogenous motivation, define their own development goals and plan their own development process according to the learning resources, platforms, conditions and opportunities provided by the school, in the meantime, gradually improving their learning autonomy and initiative, constantly promoting cognitive learning, comprehensive learning, investigative learning and research-based learning patterns, motivating the change from shallow level learning to deep level learning to improve learning ability and effect.

"Teaching" refers to that teachers focus on the growth of students, through improving the teaching mode, training students' inner potential and promoting the transformation of students' learning mode in the implementation of general education, professional education, innovative entrepreneurship education and students' development education, so as to obtain the all-rounded development as well as the improvement of the professional quality and ability, and also to promote the personal growth of students.

"Innovative practice experience" refers to that under the guidance of teachers, 
students continuously strengthen self-education and learn to face the real-self, constantly discover and understand themselves, look within their inner interests and passions, and explore their potential and creativity. Through "doing by learning" and "learning by doing" innovation practice experience, students learn to overcome frustration, enjoy the joy of learning and growing, and be the master of self-learning.

\section{Reform Content of Talent Cultivation Mode}

The research mainly focuses on the fundamental problem of talent training: "for whom to cultivate talent, cultivating what kind of talent, and how to cultivate talent".

\subsection{Build a Diversified Cultivation System and Promote the Transformation of Students' Learning Mode}

Comprehensively innovate the talent cultivation system structure, and construct a curriculum system consisting general education courses, professional basic courses, main core courses, professional oriented courses, scientific research training and comprehensive practical teaching, which expands the independent learning at multiple levels and dimensions, and promotes transformation from passive learning to active learning of students.

1) Reduce the total credits of courses to about 169 credits, increase the proportion of elective courses, and provide more space for self-regulated learning.

2) Reconstruct the curriculum system of general education. Strengthen and reform ideological and political theory teaching, focus on cultivating students to establish a correct outlook on life, values and world. Build five categories of general elective courses to promote the integrated development of students' humanistic quality and scientific quality, cultivate students to think and deal with problems from an interdisciplinary perspective enabling the comprehensive development.

3) Strengthen the reform of teachers' teaching mode to enable students fully prepared for comprehensive learning and discussion learning under the guidance of teachers.

4) Carry out scientific research training programs such as innovation and entrepreneurship, discipline competitions to promote students' research-based learning.

\subsection{Deepen the Reform of Curriculum Structure and Promote the Transformation of Teachers' Teaching Mode}

Curriculum is the major way of talent cultivation. The focus of curriculum reform and construction has changed from teaching content to teaching methods. The key is to promote the reform of teachers' teaching methods and carry forward the full function of teachers in guiding and leading during the process of talent cultivation. 
1) Based on professional basic courses and main core courses, carry out the teaching mode reform, implementing "medium-class teaching, small-class discussion, one-to-one Q\&A" teaching pattern, and the small-class discussion learning are presided over and guided by teachers. Strengthen the assessment of students' learning process and establish a structural evaluation mechanism of course assessment.

2) During the implementation of college students' innovative entrepreneurship training program and discipline competition program, instructors and students form a miniature academic community where teachers play a guiding role enabling students to get academic training in research-based learning.

\subsection{Build a Platform for Entrepreneurship and Innovation Education to Enhance Students' Practical Experience}

In addition to increasing the designing, comprehensive, innovative experimental projects and professional practice training, in order to reform the traditional practice teaching mode, the College of Electronic Information Engineering of Inner Mongolia University builds an innovative entrepreneurship education platform for students to cultivate innovative spirit, innovative ability, and pioneering consciousness, so that students can get practice experience in the innovative process of "doing by learning" and "learning by doing".

1) Implement undergraduate innovation and entrepreneurship training program to increase the proportion of students participating in the projects, letting most undergraduates receive comprehensive and systematic innovative entrepreneurship training involving topic selection, project declaration, project implementation, innovation exploration, and achievement writing.

2) Strengthen the construction of undergraduate teaching laboratory, such as "Innovation Laboratory" of Inner Mongolia University and other practical training bases, implement the institution of three semesters and laboratory sharing, and provide conditions and institutional guarantee for students' in-depth learning such as cooperative learning and research-based learning.

\section{Reform Measures of Talent Cultivation Mode}

The reform measures are mainly aimed at the talent training mode of "Learning + Teaching + Innovative Practical Experience".

\subsection{Promote the Transformation of Students' Learning Mode}

Focusing on the fundamental problem of "who is learning, for whom and how to learn" in students, through innovative curriculum structure and the reform of talent cultivation mode, expand the space for students' multi-level multi-dimensional independent learning by promoting cognitive learning, comprehensive learning, investigative learning and research-based learning patterns, to motivate the change from shallow level learning to deep level learning, and from external incentive guided learning to internal driven learning, effectively improve students' 
learning abilities and enhance their learning subjectivities.

\subsection{Promote the Transformation of Teachers' Teaching Mode}

Focusing on the fundamental problem of "who is teaching, for whom and how to teach", through the course construction and reform, construct platform for students' innovative practice and establish incentive mechanism for teachers to fully arouse the enthusiasm of teachers' motivation. Constructing the multi-teaching pattern composed of classroom teaching, discussion guidance, project guidance and growth guidance, carry forward the full function of teachers' leading role during the process of course teaching and investigative learning, and guiding role in growth of students, so as to improve teachers' teaching ability and effect.

\subsection{Promote the Transformation of Innovative Practice Experience}

Focusing on the fundamental problem of "who is doing, for whom and what to do" in innovative practice experience, through the resources for teaching and scientific research as a whole, construct platforms for students' innovative practice education, strengthen the ability of "doing by learning" and "learning by doing" of students. Building the innovative practice education system composed of experimental practice and training, innovation and entrepreneurship training programs and discipline competitions, arouse the initiative of independent innovation practice, innovative spirit, entrepreneurial consciousness and ability of innovation and entrepreneurship, so that students can experience the pleasure brought by innovative practice experience and the happiness generated by cooperative learning enhancing the psychological energy to resist failure.

\section{Practical Effect of Talent Cultivation Mode}

1) Promote the transition from traditional teaching mode to "learning + teaching + innovative practice experience" ternary supporting talent cultivation mode enhancing self-directed learning and self-improvement. Correctly and effectively guide the supporting role of innovative practice experience in talent cultivation, and promote students to become masters of their own growth and progress in learning. Motivate the change from passive learning to the pursuit of success and innovation incentives, guiding students to constantly discover their inner passion and ignite the dream of achieving success.

2) Update the concept of knowledge and learning, not only limited to readymade systematic knowledge, but also need to be aware of how knowledge is generated, evolved, created and applied, and also think about what is not enough, where the critical spirit of reflection should play an important leading role in innovation. Reform the teaching methods, introduce such as independent, inquiry, heuristic, interactive, participatory, experiential and other teaching methods, as well as establish a self-learning self-organizing teaching system and 
strengthen knowledge processing methods. In addition to the basic knowledge and skills required for new learning expectations, other aspects should be considered such as quality, will, passion, responsibility, conscientiousness, self-control, critical innovative thinking, flexibility, aggressiveness, communication ability, leadership, team spirit, broad vision and so on.

3) Emphasizing problem orientation, many old learning methods are inefficient and weak pertinence, due to their vague assumptions for the future and do not grasp the right directions. It is necessary to give prominence to problem orientation, adopt reverse thinking, promote learning and research from the needs of the time and market trends, and attach importance to the ability of suggesting and realizing ideas. In a relaxed and interactive academic freedom and individual freedom atmosphere, enhance innovative practice experience, incorporating passion, imagination, discernment, judgment, innovation opportunity into talent cultivation system. Make creative innovation be respected and let students be confident through innovative entrepreneurship practice experience, specifically speaking, ranging from discovery of ideas, learning, exploration, improvement to value formation, which stimulates the acquisition of knowledge and professional skills.

4) To change the separation of teaching and scientific research, grasp the unity of the two, and promote the combination of them, establishing new mode of integration and promotion between teaching and scientific research. In the implementation of the new mode, the role of scientific research in promoting teaching should be highlighted, and the teaching guided and supported by scientific research should be advocated. In other words, combine teaching with research.

\section{Conclusion}

Through research and practice, personality development of students is fully guaranteed. Taking students as the center, as well as students' all-rounded development and social needs as the guidance, strengthen students' growth education, enhance students' subjectivity, stimulate learning interest and initiative, reform the teaching mode, transform the learning mode, and innovate students' academic evaluation mechanism, reinforce students' innovative practice experience, optimize teaching content, improve teaching guarantee, and build a student-centered innovative talent cultivation mode in the new era.

\section{Funding}

This work was financially supported by New Engineering Research and Practice Project of the Ministry of Education (No. E-ZDH20201607).

\section{Conflicts of Interest}

The authors declare no conflicts of interest regarding the publication of this paper. 


\section{References}

Li, J. Z. (2008). Theoretical Significance and Practical Enlightenment of "Student-Centered" Education Concept. Chinese University Teaching, 4, 54-56.

Ministry of Education (2012). Several Opinions of Ministry of Education on Comprehensively Improving the Quality of Higher Education.

http://www.moe.gov.cn/srcsite/A08/s7056/201203/t20120316 146673.html

Xu, S. H., Yao, J. G., \& Cao, J. (2018). Exploration and Practice of "Student-Centered" Talent Training Mode in Youjiang Medical College for Nationalities. Journal of Youjiang Medical University for Nationalities, 40, 495-498.

$\mathrm{Yu}$, J. (2018). Establishing the Student-Centered Concept Is the Key to Improving Talent Cultivation Ability. China Higher Education, 3, 42-44.

https://d.wanfangdata.com.cn/periodical/zggdjy201803013 